\title{
From ancient to modern: Greek literature translated to Arabic
}

\author{
Dr. Manolis Margolis \\ Ph.D in Modern Greek Literature \\ Director of the Greek Cultural \\ Foundation of Alexandria
}

The treatises on European languages, which extensively study the nahdah - the intellectual movement which emerges from within Egypt the second half of the $19^{\text {th }} \mathrm{c}$. and lasts until the first half of the $20^{\text {th }} \mathrm{c}$. - usually devote their first chapters to the initial stage of translation and adaptation in Arabic - of certain indicative texts from the European novel, short story, theater, as well as from the European philosophical, sociological and political thought. It is a usual phenomenon that a translation stage should precede the main period of flourishing and innovative creation of a certain literature, the Arabic one in this particular case, which, during that time, was in the stage of searching new ways of self-expression. Around the $19^{\text {th }} \mathrm{c}$., Arabic literature gradually evolves from the dominant until then oral way of transmitting the middle age romances and epics - such as of Antar, of Bani Hilal, etc. and which addresses itself to a multiple audience, to the written text of an eponymous writer who, individually addresses himself to the educated inhabitants of the city. Thus, this Arabic literature needs to look towards other literatures which, since some time, have already been involved in the written form of speech, in order to borrow from them a new literary expression able to respond to the anticipations of a new individualized reading audience.

Simultaneously, it should be noted that the $19^{\text {th }} \mathrm{c}$. Egyptian society is being overwhelmed by educational foundations and cultural institutions, among which European scholars, mainly French and British, hold a predominant position. Thus, the Egyptian educated elite studies in Western European universities, as well as in educational centers within Egypt, under the guidance of European scholars. From within this colonial and competitive environment, Egyptian national conscience begins to awaken; its representatives aim at creating a national literature (adab) and national 
art, receptive to European borrowing and influences, but whose main objective will be to confirm the notion of existence, throughout the centuries, of an "eternal Egypt" with its very own characteristics.

Although, within Nahdah's translation movement, an important part, for the first time, is taken up by the translations, in Arabic, of ancient Greek literature texts, this phenomenon has not, until now, been recorded by the relevant European studies. Even worse, rare are the relevant to this issue studies undertaken by contemporary Greek scholars, regardless of the fact that some intellectuals from within Egypt's Greek community had been broadly following this movement development by publishing relevant articles in the local Greek press.

In this present speech I intend to focus my attempts on two issues: the perception of this particular tendency by the Greek colony's exclusive circle of arabologists, particularly of Evgenios Michailidis, who is also their leading representative, as well as the ideological belief of the Egyptian intellectuals who are more directly related to it, examining the opinions of Taha Husayn, the most distinguished personality among them. Next, I intend to examine the emerging interest for the neo-Hellenic literature, which becomes more concrete at the beginning of "60ies, with Ali Nour as its forerunner.

The first markings of interest towards the ancient Greek literature can be traced at around 1841, when Rifa'a al-Tahtawi (1801-1873) is the Director of a Bureau of Translation operating within the School of Languages which has been set up in 1836. According to Albert hourani, in his remarkable book "Arabic thought in the liberal age (1798-1939)", the Egyptian Imam, during his five years tenure in Paris, among texts of French philosophers and intellectuals of the Enlightment, read "Greek philosophy and mythology" as well. Later on, as Translation office director, he guided and oversaw an important number of translations. Among history works on the ancient world, on the Middle Ages, on the French kings, etc., a book on the Greek philosophers was also translated.

It is well known that the Syrian-Lebanese Christian scholars who emigrated and established themselves in Egypt after mid-19 ${ }^{\text {th }}$ c., played an important role within the translation movement of the time. Most of them were multi-lingual and, simultaneously, inaugurated the publication of a series of widely circulated newspapers and magazines.

From the point onwards, though, let us follow the Egyptian translation movement from the point of view of Evgenios Michalidis, as well as that of the other scholars of the Greek community. The Arab-learned 
members of this community, in the time span between the two world wars, are among the first to realize the developments in many fields of the Egyptian society, developments which become more apparent right after the end of the First World War. Saad Zaghloul's 1919 thawra (revolution) against colonialism signals the maturity of the Egyptian national conscience. The Egyptian national movement is contesting, this time with higher prospects of success than those of similar attempts in the past, the acquisition of an independent nation. The national sentiment is clearly reflected in the area of culture. Original novels are published, as well as collections of short stories, theatrical plays, literary critics, poets are following the contemporary European currents, while remarkable as well is the production of fine arts.

Between 1927 and 1929, in the Alexandria Patriarchate's magazine Ecclisiastikos Faros (Ecclesiastic Lighthouse), Michailidis is publishing eight articles, presenting an equal number of Nahdah's representatives. A few years earlier, another cluster of articles of his are being published in the Alexandrian magazine Faros (Lighthouse). In the issue of June 30, 1925, he is talking about the work of Sulayman al-Bustani $(1856=19250$. After underlined al-Bustani's contribution to the writing of the Arabic encyclopedia, he is particularly praising the fact time the Arabic literature with an exceptional translation of the Iliad. It is worth mentioning that, in the subtitle of the article he is identifying himself as " a lover of Hellenic antiquity". The Greek-Egyptian scholar is coming back on the issue of the fate of the Iliad within the Arabic literature twice again. First, in 1937, with the text "Homer in the Arabic language and literature", published in the Panaigyptia, he is trying to interpret the reason for which the Homeric epics had not been considered worthy of translation in Baghdad during the middle ages. In contrast to the faraway past, he believes that al-Bustani's deed, whom he considers as one "of the contemporary Greek learned and Philellenes" constitutes an innovation within the Arabic literature.

Finally, in 1958, after two decades, in an article in the magazine $O$ Vias, Michailidis records the Iliad's four translations which have been published during that in-between period (1904-1958). At the same time, he differentiates between the recent Arabic translation movement - particularly of concern to the ancient Greek literature - and that (translation movement) which flourished in Baghdad under the rule of the Abbasids. The dominant impetus of the first movement (the recent Arabic one) is the translation, in Arabic, of literary texts, such as epic and dramatic poetry, while the second $1 \cdot \mathrm{V}$ 
one (movement) focused on texts from various scientific fields (philosophy, medicine, astronomy, geography, algebra, geometry, etc) belonging to the classical Greek civilization.

Referring himself to Lutfi al-Sayyid, in a 1928 article, Michailidis believes that he is "one of the cornerstones of the more recent in Egypt intellectual movement and awakening". Next, he underlines the closeness of Lutfi al-Sayyid's thought to the Aristotelian philosophy, a fact that has led him to translate, from French to Arabic, the Ethica Nicomachea. This piece of work, according to Michailidis, "honors both the translator and his native country".

Four years earlier, in 1924, Panos Patrikios, in a relevant article published in the newspaper Tachydromos, notes and praises the Aristotelian oeuvre's translation by Lutfi al-Sayyid. Simultaneously, he is translating in Greek that particular poem of Ahmad Shawqi, which celebrates Aristotle and for which (poem) the poet was inspired by Lutfi al-Sayyid's translation feat. Lastly, praising Taha Husayn's work and personality, Michailidis notes that "he is a phillhelene and possibly ... the only Egyptian who loves the ancient Greek (culture)". Even though he does not record the translation work he has done from the ancient Greek literature, he implies an intimate knowledge. In an article appearing in the Panaigyptia of June 1931, he praises the decision of newly established Theatre Institute's Senate (1930) to award to the Egyptian scholar the translation, in Arabic, of Sophocles's Antigone. Moreover, he considers it his duty to indicate to the candidate translator to base himself directly to the ancient Greek original, ignoring Antigone's other translations in various European languages, since "he is a connoisseur of the ancient Greek language". Michailidis's main incentive in the promotion of the particular Egyptian scholars is the relation they themselves develop with the works of the ancient Greek literature. It would seem that he possesses the certainty that this involvement with the ancient Greek literature, as well as the classical education that some scholars have acquired, constitute the adequate base for the reference to common cultural roots. Their enhancement drawing attention to these cultural origins may contribute to the solid foundation and further strengthening of the centuriesold intellectual ties of friendship between the Greek and the Egyptian side. Similar views are also held on the side of the Egyptian, Europeaninfluenced scholars as well. A better example is encountered in the opinions of Taha Husayn, presented in his book The future of culture in Egypt, published in 1938. In this programmed work, the author states his aspiration regarding the way education and culture should exist in Egypt, while 


\section{Manolis Margolis}

country possessing independence and home rule. Thus, he is asking the, crucial for its time, question:

"Is Egypt of the East or of the West? Naturally, I mean East or West in the cultural, not the geographical sense".

After having clarified the terms' definition, he concludes:

"It would be a waste of time and effort to set forth in detail the ties binding Egypt to the ancient Greco-Aegean civilization [...] The Egyptian mind has had regular, peaceful, and mutually beneficial relations only with the Near East and Greece. In short, it has been influenced from earliest times by the Mediterranean Sea and the various people living around it".

Almost simultaneously, in the ' 30 's, Michailidis is requesting from Greece's universities to create a department of Arabic studies, while Taha Husayn, within the framework of reciprocity, is trying to establish, in Cairo University, a department of neo-Hellenic studies.

However, the first Arabic translations of texts from the neo-Hellenic literature publically appear only at the beginning of 1960 . This is the time when the, numerous and spread throughout the country, Greek community, en masse begins to abandon Egypt. It is then that some extracts of the works of Taha Husayn and of Tawfiq al-Hakim become known to the Greek public through the Cairo newspaper I Foni, translated from French by the novelist Stratis Tsirkas. But this is a totally different subject, that needs to be treated in a separate paper altogether.

Aly Nour, teacher of the Arabic language and inspector, at the time, of the Schools of the Alexandria Greek Community is, most probably, the first to translate C. P. Cavafis. In the November 1961 issue of the multilingual (simultaneously Greek, Arabic, French and English) magazine that Michailidis is publishing in Alexandria under the title Deltion tou Kentrou Ellinikon Spoudon, Aly Nour signs the Arabic rendering of three of Cavafi's poems. In the magazine's following issues are published some of the ninety five poems from the anthology of neo-Hellenic poetry translated by the Bishop of Syria's Aleppo, Elias Mouad.

Since then, Naeem Attia holds a significant position in the abovementioned field, with many books under his belt. Still, it shall be necessary 1.9 
to reach the $20^{\text {th }}$ century's last decade in order to witness a revival of the interest in neo-Hellenic literature, and particularly in poetry. This impulse was given by the unforgettable Kostis Moskof, at that time the Cultural Counselor of the Embassy of Greece in Cairo. During the 90s, among others, Cavafi's poems are published, translated by Naeem Attia and the Hellenist professor of Cairo University Hamdy Ibrahim who, later edited an anthology of neo-Hellenic poetry and the novel The life of Ismail Feriq Pasha of Greek novelist Rea Galannaki.

At the same time, besides the Academics specialized in classical studies, an increased interest is noted among circles of Egyptian poets. For example, Rifaat Salam is translating from English two tomes of Yannis Ritsos' poetry.

However, the common trait of all of these tendencies is their scanty and not systematic approach. It is necessary that all various and verified efforts be united and incorporated within a long-term framework and programme which will aim at the meaningful and deeper mutual understanding of our contemporary cultural identity.

Therefore, today more than ever, is urgent the lasting request, since the 1930s, of the creation of even only one, but well organized, department of neo-Hellenic studies, able to implement, in a systematic way, among other issues, the translation programme. 


\section{Bibliography}

1. Awad Louis, The literature of ideas in Egypt, Scholars Press, Atlanta, 1986.

2. Badawi M. M., ed., Modern Arabic literature, Cambridge University Press, Cambridge, 1992.

3. Fanus Wajih, "Sulayman al-Bustani and comparative literary studies in Arabic", Journal of Arabic literature, vol. 17, 1986, 105-119.

4. Hourani Albert, Arabic thought in the liberal age, Oxford University Press, London, 1963.

5. Kitroeff Alexander, The Greeks in Egypt, 1919-1937. Ethnicity and class, Ithaca Press, London, 1989.

6. Maragoulis Manolis, "Kairos na synxronisthomen": I Aigyptos apo ti skopia tis aigyptiotikis dianoisis tou mesopolemou, unpublished Ph.D. dissertation, Nicosia Cyprus, 2006.

7. Sharabi Hisham, Arab intellectuals and the West: The formative years, 1875-1914, The John Hopkins Press, Baltimore \& London, 1970. 